\title{
Northward Heat Flux in Midwest Summers
}

\author{
Kern E. Kenyon \\ 4632 North Lane, Del Mar, USA \\ Email: Kernken@aol.com
}

Received July 27, 2013; revised August 29, 2013; accepted September 26, 2013

Copyright (C) 2013 Kern E. Kenyon. This is an open access article distributed under the Creative Commons Attribution License, which permits unrestricted use, distribution, and reproduction in any medium, provided the original work is properly cited.

\begin{abstract}
Watching the winds in northwest Iowa during more than 30 summers has led me to two conclusions about the local atmosphere at ground level: there is a net northward transport of heat and water taking place throughout the summer; warm humid winds from the south continually alternate with cool dry winds from the north. The proposed northward heat transfer is consistent with the constraint, placed on the motions of the oceans and the atmosphere, of the earth's heat balance due to the increased absorption of solar radiation at low latitudes compared to that at high latitudes. At mid-latitudes in the interior of continents, like North America, it is the job of the atmosphere alone to constantly help satisfy the global heat balance. Although qualitative in nature, the predicted northward heat flux is strongly based on frequent observations over lengthy time intervals.
\end{abstract}

Keywords: Northward Heat Flux; Midwest Summers

\section{Introduction}

The following discussion is based on more than 30 summers spent at one particular place in northwest Iowa. No measurements were taken or recorded by me. Such data are surely available to those who are interested in them. But I watched the winds with a keen interest because in San Diego, where I grew up, it is very seldom that the wind blows with any significant strength in summer. One July 4 in northwest Iowa it was cold enough that I turned on the heater in the car. In a different year a couple of days were so hot that cows died in their pastures. These extremes are rare, but blowing hot and then cold and back again is expected all summer long in this part of the country. Precious few are the days of dead calm.

Over the 30-year period leading up to the present time, the wind direction and some notion of strength are made visible by the town wind mill against the background of roads, which are oriented on an east/west and north/south grid. [Wind mills are located in places that are known to have plenty of wind, and the one in our town was one of the first to be built in the whole state]. Also in moving around town one customarily looks at the way the flags are pointing in this typically patriotic community. In addition, from our house on a small lake we know at any time of day which way the wind is blowing from the ruffles it makes on the water surface.

No comments on the atmosphere are offered for the winter season in northwest Iowa because my personal experience is very limited at this time of year. However, some similarities to the summer heat balance at least, which are discussed below, are conjectured to be very likely going on in winter.

\section{Observations}

Three facts and two conclusions based on them are as follows:

1) Most of the time during the summer in northwest Iowa the winds continually alternate between those with a northward and those with a southward component.

2) Winds going north are relatively warm and humid.

3) Winds going south are relatively cool and dry.

From facts 2) and 3) come two conclusions about the local atmosphere at ground level:

1) Averaged over several alternation cycles it is selfevident that at the location of the observations there is a net northward transport of heat due to the wind motions. This qualitative prediction is based on numerous sightings over an extended time interval.

2) There is also a net transport of fresh water northward.

\section{Discussion}

The proposed northward atmospheric heat flow is in accordance with the general requirement of the earth's heat balance placed on the motions of the atmosphere and the 
oceans due to the excess of absorbed solar radiation at low latitudes compared to that at high latitudes, while the outgoing long wave radiation is nearly independent of latitude [1-3]. Over the interior of the continents, however, it is the job of the atmosphere by itself to accomplish some of the global heat transfer. It is not readily believable to suppose that within the 3000 mile east/west extent of North America, for example, adjustments to the heat balance of the atmosphere are not occurring on a daily basis, and these adjustments only take place over the oceans, which are busy carrying out their own heat balance adjustments.

A further requirement of conclusion II is that for an equilibrium to be maintained water must eventually, directly or indirectly, be returned south, since in summer it originally came mainly from the ocean in the Gulf of Mexico. An amazing fact in this connection is that with only one exception (the Red River going north), in Iowa and in the several states surrounding Iowa, and even beyond that, the rivers flow with a southward component, dumping their load into the Gulf of Mexico. Thus, there appears to be a direct and at least an approximate regional water balance taking place, which possibly might be made quantitative.

On the other hand, in the winter the source of the moisture for the rivers of the Midwest is mainly the North Pacific due to the rain storms that enter through Washington, Oregon and California and move eastward. This means there must be a net transfer of fresh water from the North Pacific to the North Atlantic in winter, since almost all the Midwest rivers drain into the Gulf of Mexico. How does the North Pacific get that fresh water back?

None of the two conclusions, I and II, is qualitatively changed if the alternating northward/southward winds are not exactly due north or due south, although that turns out to be very nearly the case much of the time in northwest Iowa. It is not important that the alternation process at a fixed location does not have a constant frequency. Also there is no problem if the northward/ southward winds might slowly drift sideways (east or west). Finally, the longitudinal band width of the north/ south winds is not critically important either. These flexibilities of the allowable wind characteristics just enumerated reflect the overall looseness of the earth's heat budget constraint.

Since conclusions I and II are founded on repeated observations over a fairly long period of time, they are independent of the physical cause of the alternating northward and southward winds, which therefore remains an interesting subject to study in the future.

Conservation of mass need not apply at a single fixed location, so when averaged over time the northward mass flux does not have to exactly equal the southward mass flux. For example, between the Rockies and a north/ south line to the east, which has no name but for convenience here is called the "humidity" line, the land is always dry in summer. To the east of the humidity line, the land becomes green. This humidity line passes south through the western part of South Dakota (Bad Lands), Nebraska, Kansas, Oklahoma and on through west Texas. Apparently, on the average, very little or no moist air from the south (Gulf of Mexico) makes its way into the dry zone west of the humidity line and east of the Rockies. Cool dry air from the north (Canada) can and probably does flow south through the dry zone in summer, not as a steady flow but in pulses which have a positive mean southward mass flux.

Consistent with the picture described above is the notion that there may be a physical boundary blocking the flow, particularly on the cool dry winds that come from the north past northwest Iowa. In flowing south these winds will of course experience the effect of the Coriolis force, which is to try to move a southward flow to the west. If the south wind is free to move west, and depending on the longitudinal bandwidth of the southward flow, sooner or later the effect of the Coriolis force will be partially or completely counteracted by the barrier of the Rocky Mountains. Given the existence of the dry zone east of the Rockies, the suggestion arises that the wind out of the north tends to hug the mountains on its right side facing in the direction of the flow.

As a consequence of the above chain of the reasoning, it is even conceivable that the wind in northwest Iowa spends somewhat more time blowing out of the south than it does out of the north, since in the dry zone next to the mountains the wind probably spends more time blowing out of the north and very little or no time coming from the south. An analysis of actual data from a given location would determine the amount of imbalance.

Another consideration that makes it unlikely that moist air could enter the dry zone east of the Rockies is that if warm air from the south starts to move north from the Gulf of Mexico, the Coriolis force will attempt to push it to the east, and if it is free to do so, shift it further away from the Rocky Mountains. On the right side of the northward flowing warm wind, the mountains near the East Coast are much less of a barrier to a deviation of the warm winds to the east than the Rockies are to a deviation to the west of a southward cold wind.

\section{REFERENCES}

[1] H. U. Sverdrup, "Transport of Heat by the Currents of the North Atlantic and North Pacific Oceans, in Festskrift til,” John Griegs Boktrykkeri, Bergen, 1956, pp. 226-236.

[2] T. H. Vonder Haar and A. H. Oort, "New Estimate of 
Annual Poleward Energy Transport by Northern Hemisphere Oceans,” Journal of Physical Oceanography, Vol. 3, No. 2, 1973, pp. 169-172.

http://dx.doi.org/10.1175/1520-0485(1973)003<0169:NE OAPE $>2.0 . \mathrm{CO} ; 2$
[3] K. E. Kenyon, "A Shallow Northeastward Current in the North Pacific,” Journal of Geophysical Research, Vol. 86, No. C7, 1981, pp. 6529-6536.

http://dx.doi.org/10.1029/JC086iC07p06529 